\title{
Students' Ability in Comprehending Vocabularies in Mathematics: A case at Islamic Junior High School (Madrasah) in North Sumatera
}

\section{Mara Samin Lubis}

marasmin@yahoo.com

State Islamic University of North Sumatra

\begin{abstract}
This study aimed to describe students' ability to comprehend the meaning of mathematical vocabulary in one Madrasah in North Sumatera. This research was a qualitative research, with a phenomenology approach. The participants of this research were the seventh-grade students of one Islamic Junior High School (Madrasah) who had high, medium and low ability. The data were collected by using observation, interview and documentation, and were analyzed by using Miles and Huberman models. The results of this study showed that students who had high ability could master three indicators of the ability to understand vocabulary in mathematics; interpreting, summarizing, and explaining. For students who had moderate abilities, they only mastered two indicators of the ability to understand mathematical vocabulary; interpreting and summarizing. For students who had low ability, they only mastered one indicator; interpreting or in other words interpreting vocabulary used in mathematics in their own words.
\end{abstract}

Keywords: mathematics, vocabulary, understanding ability

\section{Introduction}

Education is one of the main things that must be owned and developed both in the scope of micro and macro life. In the scope of macro (state) of life, the prosperity of a country can be seen from the quality of education in the country. A country is said to be progressing if the country focuses on the development of the education sector in order to improve quality human resources. Because good and quality education will produce quality human resources

Mathematics is one of the subjects which is commonly judged as a difficult subject. Most of students in the world have low ability in mathematics. As a "queen of science", mathematics has a complex purpose, that is, students are required to understand concepts of mathematics, explain the interrelationships between those concepts such as algorithms flexibly, accurately, efficiently, and precisely in solving problems, compiling evidence, or explaining mathematical ideas and statements. Solving problems in mathematics includes the ability to understand problems, designs mathematical models, completes models and interprets solutions to solve the problems, communicates the ideas with symbols, tables, diagrams, or other media to clarify situations or problems and give rise to respect for the usefulness of mathematics in life namely having curiosity, attention, and interest in learning mathematics, as well as being tenacious and confident in problem solving.

In line with that, Hasratuddin (2014) states that mathematics is a way to find answers to problems faced by humans. It is a way of using information, using knowledge of shapes and sizes, using knowledge about counting. Understanding mathematics in relation to learning 
outcomes based on curriculum demands means having mathematical competence or being competent in doing things by using mathematics. Meanwhile, having competence in several domains of individuals, professionals, and social life is the ability to master aspects of life. Consequently, mathematical competencies must be given equal meaning (perhaps the same) with the ability to understand, assess, perform, and use mathematics in the context of factual knowledge, technical skills both linguistics aspects such as grammar, and vocabulary (notation) and non-linguistics aspect such as reasoning. It can be said that mathematical competencies must be clearly recognized, including the competency to understand mathematical vocabulary.

Ability in learning includes three domains namely, cognitive, affective, and psychomotor. In this study, the ability that is very closely related to the learning process of mathematics is 'understanding ability'. In the domain of ability, 'understanding' belongs to the cognitive domain. Understanding is the result of the activities of an individual in doing something. Understanding mathematics is a fundamental aspect and the basic ability to achieve other higher mathematical abilities. According to Van de Walle (2008), understanding can be defined as a measure of the quality and quantity of relations between existing knowledge. In other words, mathematical understanding is also one of the objectives of each material delivered by the teacher in teaching mathematics because the teacher is the student's guide to achieve the expected concept. This is in accordance with Hudoyo (1985) who states that the purpose of teaching is to make the knowledge conveyed and understood by students.

In the process of learning mathematics, there will be no one who can solve mathematical cases, if they do not have the ability to understand the vocabulary in mathematics. Understanding mathematics is the goal of a process of learning mathematics itself. Therefore, mathematics must be considered and treated structurally in its implementation. In line with this, according to Krathwohl, et al. (2001), there are seven indicators of understanding processes: (1) interpreting, which means changing information from one representation to another such as interpreting something in their own words, interpreting images with words or vice versa, interpreting numbers with words and vice versa; (2) exemplifying, which means giving a specific example of a concept or principle; (3) classifying, which means classifying something or examples in the form of categories of concepts or principles; (4) summarizing, which means giving a single statement that represents presented information or abstract from a general theme; (5) inferring (concluding) which means drawing logical conclusions from the information presented; (6) comparing which means detecting similarities and differences between two or more objects, events, ideas, problems, situations; and (7) explaining which means constructing and using the causes and effects of a system model.

According to Jana (2015), vocabulary is an element in every language. With vocabulary, speakers / users of language express thoughts, desires, hopes, and feelings both verbally and in writing in various spheres of life through varied social interactions. Vocabulary plays a very important role in a language because language without vocabulary is like a tree without roots. This means that vocabulary is the main foundation which is used as a carrier of meaning in oral and written communication in order to produce sentences/expressions, statements, questions, and so forth. Thus, it can be concluded that vocabulary is all words contained in a language of certain people that contain all information about the meaning and use of words in the language. In terms of the field of science, the vocabulary found in mathematics can be called 'mathematical vocabulary'. 
According to Haji (2012), using vocabulary and notation to submit ideas is one of the abilities that must be possessed by the students in communicating in mathematics. Whereas Bell (in Kusumawati, 2015) lists basic terms in mathematics (vocabulary) which consists of 360 words found in six basic topics; quantity, measurement, time, money, place values and natural numbers. Bell's opinion is a reference that knowing mathematical vocabulary becomes an inseparable part of the process of learning mathematics, including in communicating mathematics. Thus, it can be concluded that knowing and understanding mathematical vocabulary is an important thing in order to form effective mathematical learning because by understanding mathematical vocabulary, students can master the content and can apply it in future situation.

The ability to understand mathematical vocabulary is an ability that emphasizes the condition where the students are familiar with the vocabulary, understand its definition, are able to translate or explain its meaning, are able to use vocabulary accurately when communicating, and are able to provide examples and counter examples of mathematical vocabulary found. In line with this, Silver (2013) states that one of the indicators of whether students have thoroughly understood a topic of mathematics is their ability to use important vocabulary when they speak and write that topic.

Furthermore, according to Marzano, there are eight characteristics of vocabulary development to build a background in knowledge. Following are the characteristics of developing words; 1) does not depend on definition; 2) are demonstrated in both linguistic and non-linguistic ways; 3) involving gradually in forming words through several methods; 4) teach each part of the word to improve understanding; 5) include various types of instructions for different types of words; 6) allow students to dare to play with words (manipulating words); 7) discuss with students about the words learned and 8) focus on things that have a high probability of improving academic performance.

This study aimed to describe students' ability to comprehend the meaning of mathematical vocabulary in one Madrasah in North Sumatera. The indicators of understanding ability used in this study are interpreting, summarizing, inferring (concluding), and explaining. There are some previous related studies which are related to my study. Listiawati's (2016) study concluded that, in solving mathematical problems, student success is largely determined by how students can read and understand the sentence on the mathematical problem. In line with this, Silver (2013) states that: one of the indicators of whether students have deeply understood a topic of mathematics is their ability to use important vocabulary when they speak and write the topic. In line with that, Langeness (2011) says that students who write problems in their own sentences can improve their ability to understand and solve mathematical sentence problems.

\section{Methodology}

The research design used in this study was qualitative research with a phenomenological approach. Merriam (1998) states that qualitative descriptive research with phenomenological approach is research that contains data in the form of sentences, images and schemes from oral or behavioral of people whom are observed in a research environment without statistical calculations. The research on the ability to understand students' mathematical vocabulary was conducted at one Islamic junior high school (Madrasah) in North Sumatera. The school is 
located at Pasar Huristak village, Huristak sub-district in Padanglawas. The participants of this study were seventh-grade students with high, medium and low abilities. The selection of research objects of students with high, medium and low abilities was obtained from the information of the class, the value of report cards on the report on student learning outcomes and the activeness of students during the learning process.

The instruments used to collect the data in this study were non-test instruments. The observation, interviews, and documentation were used as the instruments to collect the data. The data analysis model used was Miles and Huberman model (1994) where the data were collected from the interviews, observation and documentation were recorded and the data then were transcribed. Next, the data were carefully analysed, reanalysed and finally, the data were categorized into particular themes.

\section{Findings}

\section{High-ability students}

The results of the practice questions for T-2 students were presented in Figure 1 below:

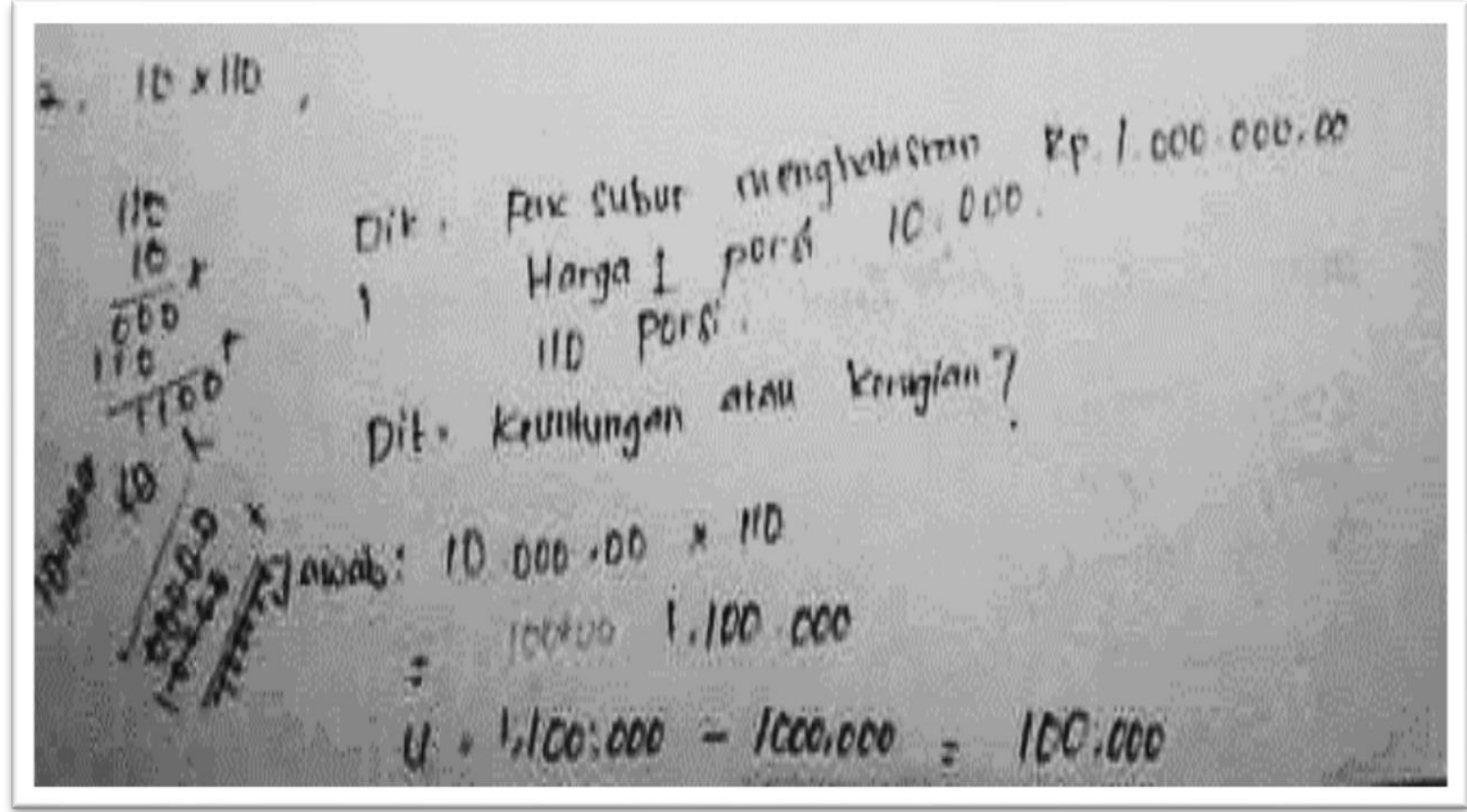

Figure 1. Results of Student Work of T-2 Number 2

Based on the results of the training, T-2 students had reached the vocabulary comprehension ability. The indicators were presented in Table 1 as follows: 
Table 1. Indicators of the Ability of Understanding Mathematical Vocabulary of T-2 Students for question no. 2

\begin{tabular}{llll}
\hline No & Indicator & Description & Explanation \\
\hline 1 & $\begin{array}{l}\text { Interpreting; interpreting } \\
\text { things in their own words }\end{array}$ & Adequate & $\begin{array}{l}\text { T-2 students were able to answer } \\
\text { what was asked in their own } \\
\text { words. }\end{array}$ \\
\hline 2 & $\begin{array}{l}\text { Summarizing; giving a Adequate } \\
\text { single statement that } \\
\text { represents the presented } \\
\text { information. }\end{array}$ & $\begin{array}{l}\text { T-2 students fulfill the indicators. } \\
\text { It was because in interviews and } \\
\text { answer sheets, they did not answer } \\
\text { the question by using notation or } \\
\text { sign in the answer sheet }\end{array}$ \\
\hline 3 & $\begin{array}{l}\text { Inferring; drawing logical } \\
\text { conclusions from the } \\
\text { presented information }\end{array}$ & $\begin{array}{l}\text { T-2 students were able to finish } \\
\text { precisely the results of the work } \\
\text { that had been done }\end{array}$ \\
\hline $4 . \quad \begin{array}{l}\text { Explaining; Explaining } \\
\text { the steps for completion of } \\
\text { verbal and writing form }\end{array}$ & $\begin{array}{l}\text { T-2 students were able to explain } \\
\text { and complete the steps both in oral } \\
\text { and written completion properly. }\end{array}$ \\
\hline
\end{tabular}

From the results of the work done by T-2 students, it was seen that T-2 students were able to fulfill the four components of the indicator. Based on the interviews conducted, the T-2 students said that they understood the problem, and were able to interpret what was meant by the question using their own words and explain them properly and correctly. Students were also able to write it into mathematical notations or symbols. The T-2 students said,

"What is known, Mr. Subur spent Rp. 1,000,000 to shop for basic commodities. The price of porridge is Rp.10,000 per serving. Today, Pak Subur can sell 110 servings. Who was asked about the question, how much is Pak Subur's income and what is being experienced by Pak Subur. "

In the interview T-2 students also explained the steps to get a solution of the question. T-2 students said,

"So, if the capital is $1,000,000$, it costs 10,000 per serving. 10,000 multiplied by 110 and the results are $1,100,000$, that's the income. "

Students were also able to deduce from the results they got, when they were asked whether Subur gained profits or lose, one of the students said,

"Mr. subur gets profit, because his income is bigger than his capital. Fortunately, $100,000.1,100,000$ less than 1,000,000. "

Based on the analysis of the results of the T- 2 students' questions and interviews, it could be said that T-2 students were also able to understand the meaning of the question proved by being able to answer and write what was known and asked from the questions. The students were also able to write with symbols and mathematical notation. They were able to conclude from the work that 
they did. Thus, it could be concluded that T-2 students were able to fulfill the four indicators; interpreting, summarizing, inferring, and explaining.

\section{Moderate students}

The results of the S-2 student practice questions were presented in Figure 2 below:

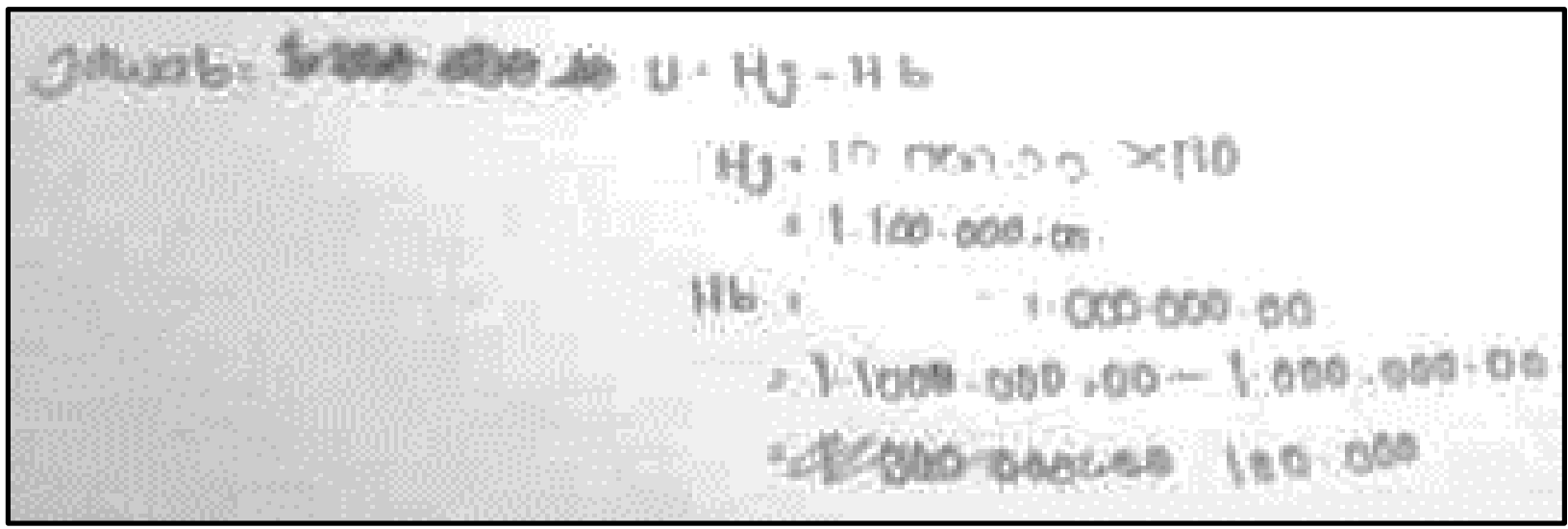

Figure 2. The results of work on S-2 students in question number 2

Based on the results of the training problem, S-2 students had reached the indicator of vocabulary comprehension ability presented in Table 2 as follows:

Table 2. Indicator of the ability to understand mathematical vocabulary of $S-2$ students in question number 2

\begin{tabular}{llll}
\hline No & \multicolumn{1}{c}{ Indicator } & Description & \multicolumn{1}{c}{ Explanation } \\
\hline 1 & $\begin{array}{l}\text { Interpreting; } \\
\text { interpreting things } \\
\text { in their own words }\end{array}$ & $\begin{array}{l}\text { S-2 students were able to interpret what was } \\
\text { meant by the question in their own words. }\end{array}$ \\
\hline 2 & $\begin{array}{l}\text { Summarizing; } \\
\text { giving a single } \\
\text { statement that Not adequate } \\
\text { represents the } \\
\text { presented } \\
\text { information. }\end{array}$ & $\begin{array}{l}\text { S-2 students did not fulfill the indicators, } \\
\text { because in interviews and answer sheets, they } \\
\text { did not make what is known and asked from the } \\
\text { question by using notation or sign in the answer } \\
\text { sheet }\end{array}$ \\
\hline 3 & $\begin{array}{l}\text { Inferring; drawing } \\
\text { logical conclusions } \\
\text { from the presented } \\
\text { information }\end{array}$ & Adequate & $\begin{array}{l}\text { S-2 students were able to conclude precisely } \\
\text { from the results of the work that has been done }\end{array}$ \\
\hline $4 . \quad \begin{array}{lll}\text { Explaining; } & \text { Adequate } & \text { S-2 students were able to explain and interpret }\end{array}$
\end{tabular}


Explanation

\begin{tabular}{|c|c|c|c|}
\hline No & Indicator & Description & Explanation \\
\hline & $\begin{array}{l}\text { Explaining the } \\
\text { steps for } \\
\text { completion } \\
\text { verbal and writing } \\
\text { form }\end{array}$ & & $\begin{array}{l}\text { the steps of completion both verbally and in } \\
\text { writing properly. }\end{array}$ \\
\hline
\end{tabular}

From the results of exercise number 2, the S-2 students were able to fulfill all four indicators. The students were able to interpret the intent of the problems. The students were able to distinguish what was known and asked from the question. As one of the students said at the interview,

"It is known that Pak Subur spent Rp. 1,000,000. the price of chicken porridge is Rp.10,000 per serving. Pak Subur can sell 110 servings. Whereas those who were asked, Mr. Subur gets profit or loss, how much is it. "

But it is very unfortunate, because students did not write down what was known and asked from the question number 2. The students were also able to explain and write down the steps in working on question number 2 and concluded it correctly. As the one of students said during interview

"The formula to look for profitable sales prices is reduced by the purchase price. So the selling price is sought first, 1,000,000 times the 110 results 1,100,000. then $1,100,000$ is less than 1,000,000 which results 100,000. Pak Subur gets 100,000 profits. "

From the results of the work done by the S-2 students, it could be seen that the students were able to interpret what was meant by the problem by using their own words. The students could deduce questions and explain the steps when working on the problem. However, the students could not write down the part that was known and asked from the question even though they could mention it but they could not write it down. From the whole process, it could be concluded that S-2 students were able to fulfill three indicators; interpreting, inferring and explaining.

\section{Low-ability students}

The work results of R-2 students in question number 2 was presented in Figure 3, namely:

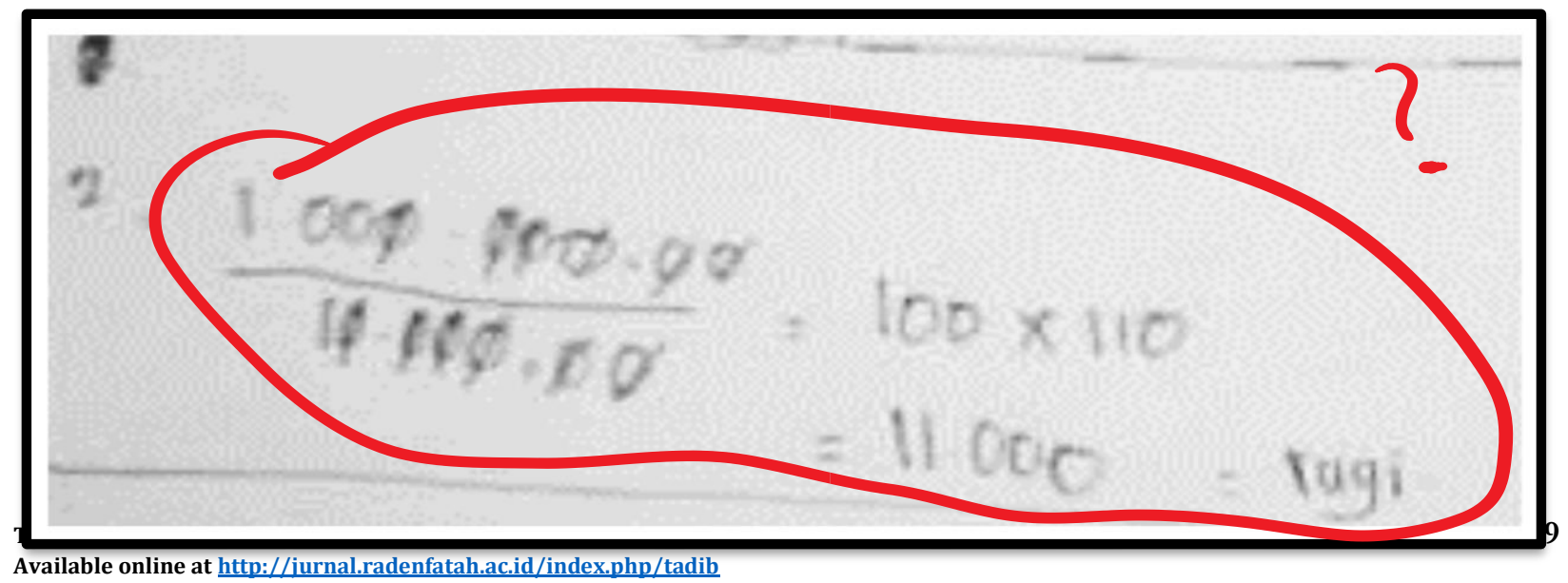


Figure 3. Results of students' work, R-2, Question Number 2

Based on the results of work on question number 2, R-2 students had reached the indicator of vocabulary comprehension ability presented in Table 3 as follows:

Table 3. Indicators of the ability to understand the mathematical vocabulary of R-2 students in question no.2.

\begin{tabular}{|c|c|c|c|}
\hline No & Indicator & Description & Explanation \\
\hline 1 & $\begin{array}{l}\text { Interpreting; } \\
\text { interpreting things in } \\
\text { their own words }\end{array}$ & Adequ & $\begin{array}{l}\text { R-2 students were able to interpret what was } \\
\text { meant by the questions in their own words. }\end{array}$ \\
\hline 2 & $\begin{array}{l}\text { Summarizing; giving a } \\
\text { single statement that } \\
\text { represents the } \\
\text { presented information. }\end{array}$ & $\begin{array}{l}\text { Not } \\
\text { adequate }\end{array}$ & $\begin{array}{l}\text { R-2 students did not meet the indicators, because } \\
\text { in interviews and answer sheets, they did not } \\
\text { make what was known and asked about by using } \\
\text { a notation or sign in the answer sheet }\end{array}$ \\
\hline 3 & 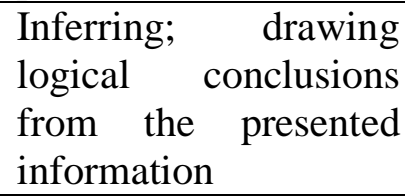 & $\begin{array}{l}\text { Not } \\
\text { adequate }\end{array}$ & $\begin{array}{l}\text { R-2 students were unable to conclude correctly } \\
\text { from the results of the work that has been done }\end{array}$ \\
\hline 4. & $\begin{array}{l}\text { Explaining; } \\
\text { Explaining the steps } \\
\text { for completion of } \\
\text { verbal and writing } \\
\text { form }\end{array}$ & $\begin{array}{l}\text { Not } \\
\text { adequate }\end{array}$ & $\begin{array}{l}\text { The R-2 students did not explain and interpret } \\
\text { the steps to resolve both verbally and written } \\
\text { properly. }\end{array}$ \\
\hline
\end{tabular}

From the questions that had been done by R-2 students, it could be seen that the students only fulfilled one indicator. When interviewing students, they knew what was known and asked about the problem. However, the students were not able to write it on a worksheet. as one of the students said at the interview

"Chicken porridge is known to be 10,000 per serving. Pak Subur spends 1,000,000 to shop. Asked by Pak Subur to get for or lose. How much is it? I did not write it on the answer sheet, because I was confused about writing it down and not getting used to. "

The students were also unable to complete the steps to solve the problem properly so the conclusions he mentions and write on the answer sheet are also wrong. As for what one of the students mentioned when interviewed

"The 1,000,000 divided by 10,000 results can be 100, then multiplied by 110 the portion of the proceeds gets 11,000 . so Mr. Subur gets a loss. "

From the results of the work done by R-2 students, it was seen that the students were only able to interpret what was meant by the problem using their own words. Whereas the students 
were not been able to explain the steps of the work well. They were not able to write down what was known and asked from the questions and wrote and explained the steps to work well. From the overall workmanship, it could be concluded that R-2 students were only able to fulfill one indicator, namely interpreting.

\section{Discussion}

Based on the analysis of the data, it was found that the ability to understand mathematical vocabulary on the interpreting indicator (interpreting), all of the three categories of students were able to interpret the questions given in their own words. However, low-ability students expressed it briefly while high-ability students completed it. It is in accordance with the research conducted by Marzono that the characteristics of a person are said to understand when he can state something which does not depend on the definition.

In summarizing's component of understanding, high-ability students were able to write down and mention what was known and answered on the worksheet. Meanwhile, students with moderate and low ability did not write it down. In the third component of inferring (concluding), the students with high and moderate abilities could conclude their results of completion correctly. While low-ability students could not conclude the results of the settlement.

In the fourth component that is explaining, high-ability students could explain the steps logically and in detail. Likewise, students with moderate abilities could explain it well. But it is shorter than high-ability students. Whereas low-ability students had tried to explain it but what he explained was so short and made him even more confused.

\section{Conclusion}

From the results of this study, it could be concluded that students who had high ability could master three indicators of the ability to understand mathematical vocabulary: 1) being able to interpret (interpreting); 2) giving a single statement (summarizing), and 3) explaining the steps. For students who had moderate ability, they could master two indicators of the ability to understand mathematical vocabulary, that was interpreting and summarizing. Then, for students who had low ability, they only mastered one indicator, that was interpreting mathematical vocabulary in their own words (interpreting). Finally, the learning patterns carried out by the teacher still used the old method, by conveying and explaining the material and then continuing the process by using student routine assignments. The teacher did not provide the opportunity for students to explore the mathematical vocabulary that had been learned.

\section{References}

Haji, S. (2012). Pengaruh pembelajaran kontekstual terhadap kemampuan komunikasi matematika siswa SMP Kota Bengkulu (The effect of contextual learning on mathematical communication skills of Bengkulu City Middle School students), Jurnal Exacta, 10(2),115-118. 
Hasratuddin, (2014). Pembelajaran Matematika Sekarang dan yang akan Datang Berbasis Karakter (Mathematics Learning Now and in the Future is Character Based), Jurnal Didaktik Matematika, 1(2), 30-42.

Hudoyo, H. (1985). Teori Belajar Dalam Proses Belajar-Mengajar Matematika (Theory of Learning in the Mathematics Teaching and Learning Process). Jakarta, Indonesia: Depdikbud.

Krathwohl, D. R., \& Anderson, L. W. (2001). A Taxonomy For Learning, Teaching and Assessing: A Revision Of Blooms Taxonomy Of Educational Objectives. New York, NY: Longman.

Kusumawati, E., \& Noor, A. J. (2014). Membaca Bacaan Matematika Bagi Mahasiswa English Learners (Reading Math for English Learners Students), Edumatica, 4(2),39-47.

Langeness, J. (2019, Januari 21). Methods to Improve Student Ability In Solving Mathematics Word Problems. Retrieved from http://www.hamline.co.iy

Listiawati, E . (2016). Pemahaman Siswa SMP Pada Masalah Kalimat Matematika (Understanding of Middle School Students in Mathematical Sentence Problems). Jurnal Apotema, 2(1) 26-35.

Merriam, S. B. (1998). Qualitative Research and Case Study Applications in Education. JosseyBass.

Miles, M. B., \& Huberman, A. M. (1994). Qualitative Data Analysis: An Expanded Sourcebook. Thousand Oaks, CA: Sage Publications.

Van de Walle, J. (2008). Matematika Sekolah Dasar dan Menengah (Primary and Secondary School Mathematics), Jakarta, Indonesia: Erlangga.

Silver., \& Hervey, F. 2013. Pengajaran Matematika Kumpulan Inti Bersama (Joint Core Teaching Mathematics Teaching), Jakarta, Indonesia: PT Indeks 